\title{
Perendaman Telur dalam Larutan Daun Ketapang (Terminalia Cattapa L ) Terhadap Daya Tetas Telur Ikan Mas (Cyprinus carpio L)
}

\section{Effects Of Immersin Of Eggs In A Solution Of Ketapang Leaves (Terminalia Cattapa L) On The Hatchability Of Carp Eggs (Cyprinus Carpio L)}

Saenal, Program Studi Pendidikan Teknologi Pertanian, Universitas Negeri Makassar

$$
\text { Email:saenalunm@gmail.com }
$$

Subari Yanto, Program Studi Pendidikan Teknologi Pertanian, Universitas Negeri Makassar

$$
\text { Email: sbyunm@gmail.com }
$$

Amirah, Program Studi Pendidikan Teknologi Pertanian, Universitas Negeri Makassar

Email:amirah.mustarin@unm.ac.id

\begin{abstract}
Abstrak
Tujuan dari penelitian ini adalah untuk mengetahui pengaruh perendaman telur dalam larutan daun ketapang (Terminalia cattapa L) terhadap daya tetas telur ikan mas. Penelitian ini merupakan penelitian eksperiment kuantitatif dengan menggunakan rancangan acak lengkap (RAL) terdiri dari tiga perlakuan. Perlakuan A dengan larutan $(1 \mathrm{~g} / \mathrm{L})$, perlakuan B (15 g/L), perlakuan C (2 g/L) dan sebagai kontrol tanpa pemberian larutan (Perlakuan $\mathrm{K})$. Percobaan ini dilakukan tiga kali perlakuan sampai didapatkan 12 unit percobaan. Data telah dianalisis menggunakan analisis sidik ragam. Hasil dari penelitian diketahui perlakuan $\mathrm{C}$ dengan dosis perendaman larutan daun ketapang $2 \mathrm{~g} / \mathrm{L}$ yaitu sebesar 94\%. Tingginya daya tetas telur ini disebabkan karena adanya kandungan tanin yang terdapat dalam larutan daun ketapang (Terminalia cattapa L) yang memberikan perlindungan bagi telur-telur pada saat perendaman.
\end{abstract}

Kata kunci: larutan, daun ketapang, daya tetas, telur, ikan mas.

\begin{abstract}
The purpose of this study was to study the effect of eggs in a solution of ketapang leaves (Terminalia cattapa L) on the hatchability of carp eggs. This research is a quantitative experimental study that uses a complete design (CRD) consisting of three preparations. Treatment $A$ with assistance $(1 \mathrm{~g} / L)$, treatment $B(15 \mathrm{~g} / L)$, treatment $C(2 \mathrm{~g} / L)$ and as a control without the aid of completion (Treatment $K$ ). This experiment was done three times until it reached 12 experimental units were obtained. Data has been analyzed using analysis of variance. The results of the study prove that the administration of $C$ with a soaking dose of ketapang leaf solution of $2 \mathrm{~g} / \mathrm{L}$ is equal to $94 \%$. The high hatchability of these eggs contains a lot of the tannin content needed in the leaves of the ketapang (Terminalia cattapa L) which protects the eggs during soaking.
\end{abstract}

Keywords: solution, ketapang leaves, hatchability, eggs, goldfish 


\section{Pendahuluan}

Indonesia merupakan salah satu negara agraris dimana sebagian besar masyarakat mencarinafkah dengan berbudidaya ikan air tawar yang, banyak digemari masyarakat dan produksi satu komoditas perikanan air tawar yang saat ini menjadi primadona di substansi balai perikanan yang mengalami peningkatan tiap tahunnya. Ikan mas memiliki beberapa keunggulan yaitu pertumbuhannya yang cepat, mudah dipelihara, memiliki nilai gizi dan nilai ekonomis yang cukup tinggi. Ikan mas atau yang juga dikenal dengan sebutan common carp adalah ikan yang sudah mendunia. Hal ini merupakan apresiasi dalam meningkatkan sektor pengembangan budidaya jenis ikan air tawar (Suseno, 2000). Berbagai sistem budidaya telah diterapkan dan terus berkembang untuk memperoleh produksi ikan mas yang maksimal. Hal ini mengakibatkan pemeliharaan ikan mas dikembangkan secara intensif. Keberhasilan suatu usaha pemijahan ikan dipengaruhi oleh faktor kematangan ikan yang akan dipijahkan, makanan yang diberikan selama pemeliharaan dan kondisi lingkungan. Pemijahan ialah cara pengeluaran sel telur pada induk betina dan sperma oleh induk jantan sehingga terjadi proses perkawinan. Menjelang memijah induk-induk ikan mas aktif mencari tempat yang rimbun seperti tanaman, air atau rumputan yang menutupi permukaan air. Substrat inilah yang nantinya akan digunakan sebagai tempat menempel telur sekaligus membantu perangsangan ketika terjadi peminjahan (Suseno,2000).

Meningkatnya usaha budidaya ikan mas disebabkan dari cara penyediaan dan distribusi benih yang baik serta tujuan tepat seperti tempat, jenis, waktu, mutu, jumlah ukuran dan tepat harga. Daun Ketapang (Terminalia catappan L) menurut Azizah (2004) menyatakan, tanaman yang fungsional karena semua bagian tanaman ketapang dimanfaatkan sebagai obat, mengandung asam humic dan tanin yang mampu mengatasi serangan jamur. Selain itu ketapang dapat mencegah berbagai macam infeksi virus dan bakteri. Dari berbagai hasil yang telah ditemukan, faktanya larutan daun ketapang dapat mencegah gangguan mikroorganisme, salah satunya fungi. Perendaman telur dalam larutan daun ketapang (Terminalia cattapa L) dapat menjadi sebuah solusi bagi pembudidaya untuk meningkatkan daya tetas telur dalam usaha budidaya ikan air tawar, khususnya ikan mas (Cyprinus carpio L). Tujuan penelitian ini untuk menganalisis pengaruh perendaman telur dan konsentrasi larutan terbaik dari larutan daun ketapang (Terminalia cattapa L) terhadap daya tetas telur ikan mas (Cyprinus carpio L). 


\section{Metode Penelitian}

Metode penelitian yang digunakanan dalam penelitian ini adalah

Alat

Alat yang digunakan adalah Thermometer, $\mathrm{pH}$ meter, DO meter, timbangan elektrik, ember, aerator/blower, kakaban, panci, kompor, batu aerasi, selang, kran, dan Blender.

\section{Bahan}

Bahan yang digunakaan dalam penelitian ini yaitu: telur ikan mas 600 butir sebagai objek uji, larutan daun ketapang sebagai objek penguji, kaporit $1 \mathrm{~kg}$ untuk menetralisir air, air tawar 30 liter sebagai air media, Aquades 3 liter sebagai pelarut, kertas saring 1 lembar sebagai penyaring larutang daun ketapang.

\section{Tempat}

Penelitian ini dilaksanakan di UPTD

Balai Benih Ikan Air Tawar (BBIAT). Bontomanai Kec.Bontomarannu, Kabupaten Gowa, Provinsi Sulawesi Selatan. Waktu penelitian ini dilaksanakan mulai tanggal 27 Juni sampai dengan 27 Juli 2019. Desain penelitian terdiri dari 4 perlakuan dan 3 kali ulangan dengan rincian terdiri dari perlakuan A (1 g/L), perlakuan B (1,5 g/L), perlakuan C (2 g/L) dan Kontrol (0 g/L). Dosis yang digunakan berdasarkan Muh. Erwin (2017). Jenis penelitian yang digunakan adalah eksperimen kuantitatif menggunakan Rancangan Acak Lengkap (RAL) dengan analisis sidik ragam yang diolah menggunakan program IBM SPSS 21. Jika analisis menunjukkan adanya pengaruh nyata, maka dilanjutkan uji Duncan dengan taraf kepercayaan 95\%.

\section{Prosedur Penelitian}

1. Wadah uji yang dipakai adalah ember sebanyak 12 buah dengan kapasitas 5 liter. Sebelum digunakan terlebih dahulu dibersihkan dan didesinfeksi, dengan menggunakan axalic acid. Kemudian wadah diberi kode perlakuan dan diisi dengan air tawar sebanyak 2,5 liter untuk setiap wadah.

2. Air yang digunakan terlebih dahulu diberi kaporit sebanyak $1 \mathrm{~kg}$ untuk menetralisir air sebagai media dalam penelitian yang dilakukan

3. Pembuatan larutan daun ketapang yaitu:

a. Daun ketapang dikumpulkan sesuai dengan kebutuhan dalam penelitian lalu dibersikan.

b. Daun ketapang ditimbang dengan berat 850 gram dan dikeringkan selama 8 sampai 12 jam.

c. Daun ketapang kering dihaluskan menggunakan blender dan direbus.

d. Daun ketapang didinginkan sampai suhu $27^{\circ} \mathrm{C}$ dan disaring dengan kertas saring. 
e. Larutan daun ketapang dimasukkan ke wadah penelitian sesuai dengan perlakuan yang dibutuhkan .

f. Telur ikan mas direndam selama 25 menit dalam wadah yang telah diisi larutan daun ketapang, tiap wadah masing-masing diisi telur ikan mas sebanyak 50 butir

g. Telur ikan mas yang telah direndam, selanjutnya diamati jumlah telur yang paling cepat menetas.

4. Perendaman telur

a. Proses pemijahan induk ikan mas dilakukan dengan seleksi telur-telur yang berhasil terbuahi.

b. Selanjutnya seleksi telur-telur yang telah terbuahi sebanyak 600 butir secara manual untuk dijadikan sampel lalu dilakukan perendaman selama 25, dengan dosis perlakuan A: $1 \mathrm{~g} / \mathrm{L}, \mathrm{B}: 1,5 \mathrm{~g} / \mathrm{L}, \mathrm{C}: 2 \mathrm{~g} / \mathrm{L}$.

c. Setelah dilakukan perendaman, telur dipindahkan ke wadah penetasan yang berisi air bersih dengan volume 2,5 Liter dan didiamkan selama kurang lebih 3 hari sampai telur menetas.

d. Setelah itu telur-telur yang telah menetas dan menjadi larva, dihitung dan dicatat semua perlakuan.

e. Data yang didapatkan kemudian dianalisis
5. Telur menetas dan lama penetasan.

a. menurut Minjoyo (2003), perhitungan telur dilakukan setelah telur menetas secara sempurna. Sedangkan menurut Zairin (2002), untuk mengetahui penetasan telur dapat dihitung dengan rumus.

$\mathrm{HR}=\frac{\text { JumlahTelur Yang Menetas }}{\text { JumlahTelur Keseluruhan }} \times 100 \%$

b. Waktu penetasan telur dihitung dengan mengamati telur-telur yang menetas setiap 6 jam selama 72 jam.

6. Pengukuran kualitas air (suhu, $\mathrm{pH}$ dan DO)

a. Ujung termometer dimasukkan ke dalam air media penetasan selama beberapa menit sampai garis merah yang terdapat pada termometer berhenti pada angka yang menunjukkan nilai suhu tersebut dan dicatat hasilnya.

b. Pengukuran $\mathrm{pH}$ dilakukan dengan memasukkan bagian ujung elektroda pH meter ke dalam air media. selanjutnya diamati sampai nilai $\mathrm{pH}$ keluar, kemudian hasilnya dicatat.

c. Pengukuran DO dengan cara DO meter dimasukkan ke dalam air media penetasan, kemudian diamati sampai nilainya keluar dan hasilnya dicatat. 


\section{Hasil dan Pembahasan}

\section{A. Perhitungan Daya Tetas}

Deskripsi data hasil penelitian pengaruh perendaman telur dalam larutan ketapang terhadap daya tetas telur menunjukkan daya tetas telur tertinggi terdapat pada perlakuan $\mathrm{C}$ dengan dosis perendaman $2 \mathrm{~g} / \mathrm{L}$ sebesar $94 \%$. Tingginya daya tetas telur ini disebabkan karena adanya kandungan tanin yang terdapat dalam larutandaun ketapang (Terminalia cattapa L) yang memberikan perlindungan bagi telur-telur pada saat perendaman dari serangan jamur Saprolegnias $s p$, yang dapat membuat telur gagal menetas. Hal ini membuktikan dengan perlakuan perendaman larutan daun ketapang berpengaruh pada daya penetasan telur ikan mas diketahui dengan nilai daya tetas telur meningkat dibandingkan tanpa perlakuan. Ningtyas, dkk (2013) menambahkan bahwa daya penetasan telur adalah lebih banyak telur yang menetas dibandingkan dengan banyaknya telur fertil.

Uji analisis ragam diketahui bahwa perlakuan perendaman ekstrak daun ketapang berpengaruh nyata pada daya tetas telur ikan mas dan membuktikan bahwa ekstrak daun ketapang bekerja aktif sebagai zat anti jamur. Senyawa yang terkandung dalam daun ketapang yang berfungsi sebagai zat anti jamur meliputi senyawa berupa flavonoid, saponin, fenolik, dan tannin (Pauly, 2001).

Data gambar 1 menunjukkan adanya perbedaan daya tetas telur pada setiap perlakuan, perendaman telur dengan menggunakan larutan daun ketapang (Terminalia cattapa L) pada perlakuan C:2 $\mathrm{g} / \mathrm{L}$ memperoleh daya tetas tertinggi yaitu 94\%, dan disusul perlakuan B:1,5 g/L penggunaan larutan daun ketapang (Terminalia cattapa L) memperoleh daya tetas $85 \%$, kemudian pada perlakuan A: 1 gL hanya memperoleh hasil $71 \%$, sedangkan Kontrol dapat menui hasil 50\% saja. Hal ini diduga kandungan tanin yang terdapat dalam larutan daun ketapang (Terminalia cattapa L) bersifat antimikroba sehingga mampu melindungi telur-telur ikan mas dari serangan jamur Saprolegnia sp. yang dapat menyebabkan telur-telur gagal menetas.

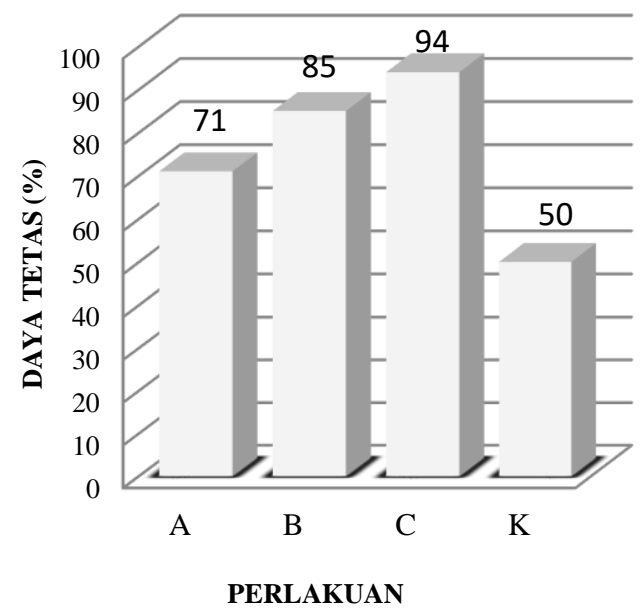

Gambar 1 Data Penelitian Daya Tetas Telur 
Hasil analisis sidik ragam daya tetas telur dapat dilihat pada tabel 1 menyatakan bahwa semua perlakuan memberikan pengaruh nyata pada daya tetas telur, dimana F_Hitung > F_tabel pada tingkat kepercayaan 95\%, sehingga dalam hal ini dilakukan Uji lanjut menggunakan uji duncan.

Hasil uji Duncan pada tabel 1. Dapat dilihat bahwa keempat sampel yang digunakan dapat memberi pengaruh nyata. Perlakuan terbaik yaitu pada perlakuan C sebanyak 94\% dan tanpa tambahan larutan daun ketapang hanya $50 \%$.

\begin{tabular}{ccccccc}
\hline SK & DB & JK & KT & F Hitung & \multicolumn{2}{c}{ F Tabel } \\
\hline Perlakuan & 3 & 3682,03 & 1227,34 & $5,64 *$ & 4,07 & 7,59 \\
\hline Galat & 8 & 1738,67 & 217,34 & & & \\
\hline Total & 11 & $5.420,7$ & & & & \\
\hline
\end{tabular}

Sumber: Hasil Analisis data Penelitian, 2019

Tabel 2. Nilai Rata-rata Perhitungan Kualitas Air

\section{B. Kualitas Air}

Hasil rata-rata perhitungan kualitas air dari pengamatan secara keseluruahan perlakuan kualitas air baik dari suhu air dan dissolved oxygen (DO) yang diukur pada pagi dan sore hari bahwa kualitas air pada media penelitian masih dalam kisaran normal. Menurut Effendi (2009), jika suhu rendah, embrio akan lebih lama tertahan dalam cangkangnya. Sebaliknya jika suhu tinggi maka akan menyebabkan embrio menetas secara prematur, namun larva secara umum tidak mampu bertahan hidup pada lingkungannya. Selain itu penetasan juga disebabkan oleh gerakan-gerakan larva akibat peningkatan suhu, intensitas cahaya dan pengurangan tekanan oksigen (Gusrina, 2008) yang ditunjukkan pada tabel 2.

\begin{tabular}{cccccc}
\hline \multirow{2}{*}{ No } & \multirow{2}{*}{ Perlakuan } & \multicolumn{2}{c}{ Suhu Air $\left({ }^{\mathbf{O}} \mathbf{C}\right)$} & \multirow{2}{*}{$\mathbf{p H}$} & \multirow{2}{*}{ DO (mg/L) } \\
\cline { 3 - 4 } 1 & Pagi & Sore & & \\
\hline 1 & K & 23,6 & 23,7 & 8,3 & 5,2 \\
\hline 2 & A & 23,7 & 26,6 & 8,4 & 5,2 \\
\hline 3 & B & 23,6 & 26,8 & 8,4 & 5,4 \\
\hline 4 & C & 23,6 & 26,6 & 8,4 & 5,3 \\
\hline
\end{tabular}

Sumber. Data Penelitian, 2019

\section{Lama Penetasan}

Puncak tertinggi terjadinya penetasan pada setiap perlakuan yakni terjadi pada jam ke-54 setelah perendaman dengan jumlah penetasan terbanyak pada perlakuan B, kemudian perlakuan A, C, dan kontrol.
Hubungan antara dosis larutan perendaman dengan jumlah penetasan telur adalah semakin tinggi dosis larutan ketapang (Terminalia cattapa L) maka akan semakin banyak telur yang menetas. Hal ini dikarenakan semakin tinggi dosis larutan 
yang digunakan maka kandungan kecepatan tetas telur adalah faktor kualitas saponinnya juga semakin tinggi. air yaitu suhu. Namun dari hasil penelitian, Kandungan saponin yang tinggi dapat kisaran suhu setiap perlakuan terbilang mendegradasi membran atau dinding sel telur sehingga larva dalam telur tersebut cepat keluar. Hal ini sesuai dengan pernyataan Inaya et al., (2015) saponin dapatmerusak membran sel telur sehingga terjadi perubahan struktur dinding sel telur yang mengakibatkan cairan di dalam sel keluar. Menurut (Roospitasari, 2002) menyatakan, suatu substansi yang disebut fertiliazine merangsang spermatozoa untuk berenang berusaha mencapai telur. Namun disisi lain hal ini juga dapat berpotensi mengakibatkan telur mati saat sel yang terdapat dalam telur belum terbentuk secara sempurna dan belum siap untuk menetas. sama akan tetapi kecepatan tetasnya berbeda-beda. Pada waktu ke 42 jam penetasan awal dengan jumlah telur yang menetas sebanyak 8 butir telur di perlakuan C (dengan dosis perendaman $2 \mathrm{~g} / \mathrm{L}$ ) penetasan lebih banyak dibandingkan perlakuan yang lainnya dari tiga kali ulangan. Selanjutnya perlakuan B (dengan dosis perendaman larutan daun ketapang sebanyak 1,5 g/L) dengan jumlah telur yang menetas yaitu 3 butir dan kontrol (dengan dosis perendaman larutan daun ketapang sebanyak $0 \mathrm{~g} / \mathrm{L}$ ) dengan jumlah telur yang menetas sebanyak 3 butir. larutan $2 \mathrm{~g} / \mathrm{L})$.

Faktor lain yang berpengaruh terhadap

\begin{tabular}{|c|c|c|c|c|c|c|c|c|c|c|c|c|c|c|}
\hline \multirow{2}{*}{ No. } & \multirow{2}{*}{ 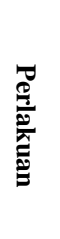 } & \multicolumn{12}{|c|}{ Jumlah telur yang menetas setiap 6 jam selama 72 jam } & \multirow[t]{2}{*}{ 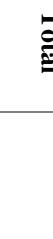 } \\
\hline & & $\stackrel{\stackrel{9}{\ddot{\Xi}}}{.}$ & $\frac{\vec{N}}{\stackrel{\Xi}{\Xi}}$ & $\underset{\stackrel{\infty}{\rightleftarrows}}{\stackrel{\infty}{\Xi}}$ & $\begin{array}{l}\underset{ \pm}{ \pm} \\
\stackrel{\Xi}{\Xi}\end{array}$ & $\begin{array}{l}\stackrel{\omega}{0} \\
\stackrel{\vec{\Xi}}{\Xi}\end{array}$ & 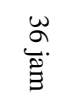 & $\frac{\stackrel{+}{\vec{N}}}{\stackrel{\Xi}{\Xi}}$ & $\frac{\stackrel{\infty}{\infty}}{\stackrel{\Xi}{\Xi}}$ & $\underset{\stackrel{u}{ \pm}}{\stackrel{\Xi}{\Xi}}$ & $\frac{\stackrel{g}{0}}{\stackrel{\cong}{\Xi}}$ & $\frac{\stackrel{\Omega}{\overparen{ٍ}}}{\Xi}$ & $\frac{N}{\stackrel{N}{\Xi}}$ & \\
\hline 1 & K1 & - & - & - & - & - & - & 1 & 10 & 10 & 5 & - & - & 26 \\
\hline 2 & K2 & - & - & - & - & - & - & 1 & 10 & 5 & 9 & 6 & 4 & 35 \\
\hline 3 & K3 & - & - & - & - & - & - & 1 & 10 & 5 & 14 & 5 & - & 35 \\
\hline 4 & A1 & - & - & - & - & - & - & - & 12 & 13 & 15 & - & - & 40 \\
\hline 5 & A2 & - & - & - & - & - & - & - & 5 & 20 & 8 & - & - & 33 \\
\hline 6 & A3 & - & - & - & - & - & - & - & 4 & 23 & 5 & - & - & 32 \\
\hline 7 & B1 & - & - & - & - & - & - & - & 3 & 25 & 10 & - & - & 38 \\
\hline 8 & B2 & - & - & - & - & - & - & 1 & 4 & 10 & 10 & 10 & 4 & 39 \\
\hline 9 & B3 & - & - & - & - & - & - & 2 & 7 & 23 & 18 & 8 & - & 50 \\
\hline 10 & $\mathrm{C} 1$ & - & - & - & - & - & - & 6 & 24 & 20 & - & - & - & 50 \\
\hline 11 & $\mathrm{C} 2$ & - & - & - & - & - & - & 1 & 7 & 10 & 10 & 12 & 10 & 50 \\
\hline 12 & C3 & - & - & - & - & - & - & 1 & 6 & 7 & 6 & 24 & - & 44 \\
\hline
\end{tabular}

Sumber. Data Pengamatan Penelitian 2019 


\section{Simpulan}

Perbedaan dosis perendaman larutan daunKetapang berpengaruh nyata terhadap daya tetas telur ikan Mas, sehingga dapat dilihat dari hasil penelitian terbaik di perlakuan $\mathrm{C}$ (dengan dosis perendaman larutan daun ketapang sebanyak $2 \mathrm{~g} / \mathrm{L}$ ). Hal ini diakibatkan adanya kandungan tanin yang terdapat dalam larutandaun ketapang (Terminalia cattapa L) yang bersifat antimikroba sehingga mampu melindungi telur-telur ikan mas dari serangan jamur Saprolegnia $s p$.

\section{Daftar Pustaka}

Azizah, U. 2004. Polimer. Direktorat Jenderal Pendidikan Dasar dan Menengah. Departemen Pendidikan Nasional.

Erwin, Muh. 2017. Optimasi Lama Peredaman Larutan Daun Ketapang Dengan Dosis Berbeda Terhadap Daya Tetes Telur Ikan Lele Dumbo. Makassar:Universitas Muhammadiya Makassar.

Effendi, H. 2009 Telaah Kualitas Air Bagi Pengelolaan Sumber daya dan Lingkungan Perairan. Yogyakarta: Kanisius.

Gusrina., 2008. Budaya Ikan Untuk SMK.

Diterbitkan oleh Direktorat Pembinaan Sekolah Menengah
Kejuruan Departemen Pendidikan Nasional Tahun 2008.

Inaya A., Kismiyati F. N. dan Subekti, S. 2015. Pengaruh Perasan Biji Pepaya (Carica papaya) Terhadap Kerusakan Telur Argulus Japonicus. Jurnal Ilmiah Perikanan dan Kelautan. Vol.7(2): 159-164.

Karu, E. 2000. Telaah Kondisi Kualitas Air di Perairan Sangihe Talaud (Teluk Lapango, Nagha dan Tahuna) suatu Studi in Situ. Skripsi Fakultas Perikanan dan Ilmu Kelauta. Manado. 57 hal.

Lesmana D.S., 2007. Reproduksi dan pembenihan ikan hias air tawar. Jakarta: Loka Riset Budidaya Ikan Hias Air Tawar Pusat Riset Perikanan Budidaya BRKP.

Mustafa A., Hasnawi, M. Paena, Rachmansyah, dan J. Sammut. 2008. Evaluasi Kesesuaian Lahan Untuk Budidaya Tambak Di Kabupaten Pinrang Provinsi Sulawesi Selatan. Riset Akuakultur. 3(2) : 241-261.

Minjoyo, H. 2003. Teknik Pembenihan Ikan Air Tawar. Jakarta. Penebar Swadaya.

Ningtyas, M. S., Ismoyati, I. H., dan Sulistyawan. 2013. Pengaruh temperatur terhadap daya tetas dan hasil tetas telur itik (Anas plathyrinchos). Jurnal Ilmiah Peternakan. Vol. 1 (1): 347-352. 
Pauly, Gilles. 2001. Cosmetic, Dermatological and Phar maceutical Use of an Extract of Terminalia catappa, United States Patent Application no. 20010002265.

Suseno. 2000. Pengolahan Usaha Pembenihan Ikan Mas. Jakarta: Penebar swadaya.

Susanto, H \& Rochdianto, A 2007. Kiat Budidaya Ikan Mas di Lahan

Sunarma, A. 2004. Peningkatan Produktifitas Usaha Lele Sangkuriang (Clariassp.).

Departemen Kelautan dan Perikanan. Direktorat Jenderal Perikanan. Hal. 1-6

Zairin, M. 2002. Teknik Pemijahan Ikan Koi \& Penanganan Daya Tetas Telur. Laboratorium Endokrinologi. Bogor: Fakultas Kelautan \& Perikanan. Institut Pertanian Bogor. 85-90. 
Halaman ini sengaja dikosongkan 